Scholarship Repository

University of Minnesota Law School

Articles

Faculty Scholarship

2007

\title{
Patents, Tax Shelters, and the Firm
}

Dan L. Burk

UC Irvine School of Law, dburk@law.uci.edu

Brett McDonnell

University of Minnesota Law School, bhm@umn.edu

Follow this and additional works at: https://scholarship.law.umn.edu/faculty_articles

Part of the Law Commons

\section{Recommended Citation}

Dan L. Burk and Brett McDonnell, Patents, Tax Shelters, and the Firm, 26 VA. TAX REV. 981 (2007), available at https://scholarship.law.umn.edu/faculty_articles/178.

This Article is brought to you for free and open access by the University of Minnesota Law School. It has been accepted for inclusion in the Faculty Scholarship collection by an authorized administrator of the Scholarship Repository. For more information, please contact lenzx009@umn.edu. 


\section{PATENTS, TAX SHELTERS, AND THE FIRM*}

Dan L. Burk" \& Brett H. McDonnell"**

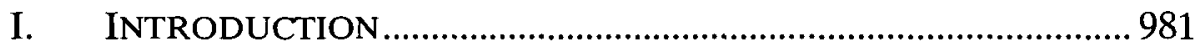

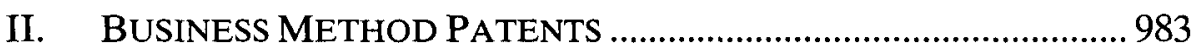

III. BUSINESS PATENTS IN AN EFFICIENT MARKET ........................986

IV. PATENTS AND THE THEORY OF THE FIRM...............................990

V. TAX Planning Without Business Method Patents ....... 992

VI. Tax Planning with Business Method Patents.................994

VII. EVAluating THE Consequences of Business Method

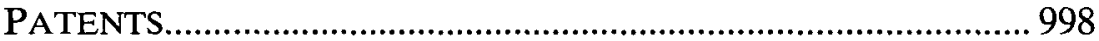

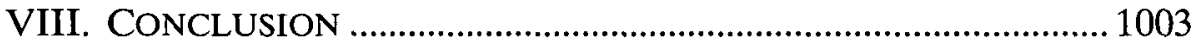

\section{INTRODUCTION}

The United States patent statute offers exclusive rights in any new and useful "process, machine, manufacture, composition of matter" or new and useful improvements on existing processes, machines, manufactures, and compositions of matter. ${ }^{1}$ Courts have read this Congressional subject matter mandate broadly, to include "anything

- Copyright 2006 by Dan L. Burk and Brett H. McDonnell.

- Oppenheimer, Wolff \& Donnelly Professor of Law, University of Minnesota.

-.. Professor of Law, University of Minnesota.

135 U.S.C. \& 101 (2006). 
under the sun" developed by humans. ${ }^{2}$ Among the processes covered by the patent statute lie a variety of innovative methods for accounting, investment, and other business strategies. ${ }^{3}$ And among such patentable business strategies lie a variety of methods for sheltering income from taxation. ${ }^{4}$

Business method patents are relative newcomers to the patent system, having been formally recognized as patentable subject matter for a little less than a decade. Explicit realization that patentable business methods necessarily include patentable tax shelters seems to be even more recent. We are aware that this realization has been the subject of controversy, and even alarm, among practitioners of tax law - hearings have been held, opinions have been voiced, and legislative action has been demanded. ${ }^{5}$ The general tenor of the reaction from the tax bar appears to be one of anxiety bordering upon panic.

But from the standpoint of patent law, none of this is particularly startling or even especially exciting. To be sure, there has been an enormous amount of discussion and controversy about the patenting of business methods. Patents are typically justified as an incentive for innovation. Numerous commentators have questioned whether such an incentive is really needed in the area of business methods and, if an incentive to innovation is needed, whether patents are the right mechanism to do the job. ${ }^{6}$ But once business methods are allowed as patentable subject matter, the presence of tax shelters among such methods is neither much of a doctrinal novelty nor much of a surprise.

Consequently, in this article we examine certain effects of tax shelter patents but take the existence of tax planning patents as given, assuming that the die for such patents was cast well over a decade ago

2 Diamond v. Chakrabarty, 447 U.S. 303 (1980).

${ }^{3}$ State Street Bank \& Trust Co. v. Signature Financial Group, Inc., 149 F.3d 1368 (Fed. Cir. 1998).

${ }^{4}$ See Richard S. Gruner, When Worlds Collide: Tax Planning Method Patents Meet Tax Practice

To Make Attorneys the Latest Patent Infringers (Oct. 21, 2006) (unpublished article, on file with the Virginia Tax Review).

${ }^{5}$ Hearing on Issues Relating to the Patenting of Tax Advice, House of Representatives Subcommittee on Select Revenue Measures of the Committee on Ways and Means, 109th Cong. 2d sess. (July 13, 2006).

6 See Rochelle Cooper Dreyfuss, Are Business Method Patents Bad for Business?, 16 Santa Clara Computer \& High TeCH. L.J. 263, (2000); Leo J. Raskind, The State Street Bank Decision: The Bad Business of Unlimited Patent Protection for Methods of Doing Business, 10 Fordham InTELl. Prop. MEdia \& ENT. L.J. 61, (1999); John R. Thomas, The Patenting of the Liberal Professions, 40 B.C. L. REV. 1139 (1999). 
and is unlikely to undergo a reversal at this late date. As a matter of U.S. patent law, the emergence of tax planning patents was probably inevitable and is almost certainly irreversible. Accepting the patent status quo allows us to move to the more interesting question of how such patents are likely to affect the firms that specialize in tax planning and the employees who move between such firms.

In approaching these questions, we draw upon our previous work regarding the role of intellectual property in the theory of the firm. We compare the emerging regime of tax investment patents with the confidentiality regime that has prevailed for investment methods in the tax planning industry. Moving beyond the standard costs and benefits analysis of patents as incentives for innovation, we discuss the likely impact of tax investment patents on the profession and industry of tax planning. We look in particular at the mobility of tax planning and investment professionals before and after the implementation of tax investment patents. We argue that the advent of tax investment patents may benefit members of the profession, as opposed to their opportunities under the alternative regime of confidentiality. In particular, it may lead to increased labor mobility and to greater entrepreneurial opportunities, with the growth of a new sector of start-ups specializing in innovative tax planning strategies. We finish by considering the social consequences of business method patents for tax planning strategies. We conclude that although the effects are mixed, and potentially negative on net, there is little that one can feasibly and desirably do within patent law to address the resulting problems without upsetting large parts of patent law.

\section{BUSINESS METHOD PATENTS}

The patentability of business methods has been manifest since the United States Court of Appeals for the Federal Circuit in State Street $B a n k^{8}$ explicitly disclaimed any prohibition on the patenting of such methods, although the patenting of such methods clearly occurred on an intermittent basis even prior to State Street. ${ }^{9}$ Patent doctrine had traditionally resisted the patenting of processes that might be carried

See Dan L. Burk \& Brett H. McDonnell, The Goldilocks Hypothesis: Balancing Intellectual Property Rights at the Boundary of the Firm, 2007 U. ILL L. REV. 575 (2007).

8149 F.3d 1368 (Fed. Cir. 1998).

${ }^{9}$ See, e.g., Paine, Webber, Jackson \& Curtis Inc. v. Merrill Lynch, Pierce, Fenner \& Smith Inc., 564 F.Supp. 1358 (D. Del. 1983) (upholding an investment system patent). 
out in the human mind, as well as the patenting of inventions consisting of written or printed indicia. ${ }^{10}$ This for many years effectively precluded the patenting of the majority of business methods, most of which involved mental processes, written methods, or both. ${ }^{11}$

But these prohibitions were largely eroded by the gradual incorporation of software into the ambit of patentable subject matter. $^{12}$ While software is at its core a set of voltages in a machine, these are represented as a type of written code that can sometimes be read by humans and sometimes read by machines - a functional form of writing that "behaves."13 Software also frequently implements calculations or numerical manipulations that could otherwise be carried out in the human mind. Consequently, the acceptance of software within patentable subject matter undermined the prohibition on which the preclusion of business methods from patent law was also grounded. $^{14}$ The implementation of business methods as software cemented this outcome, such that the State Street holding was primarily an admission of de facto practice.

This is not to say that business method patents have been placidly accepted or even that they have become uncontroversial. In one sense, the grant of any patent is a troubling practice; patents and other forms of intellectual property artificially raise prices, restrain trade, and restrict access to what would otherwise be a publicly available good. These costs of exclusivity are typically justified as being outweighed by the benefit of intellectual property as an incentive to investment. ${ }^{15}$ Without some period of legal exclusivity to recoup the cost of investment in what would otherwise be a public good, little investment in new innovation would occur, resulting in the underproduction of technical and creative works. The precise contours of the optimal package of exclusive rights to encourage innovation is hotly contested, as both the actual benefits and actual costs of such a system are enormously difficult to quantify, and the correspondence between economic theory and real-world

${ }^{10}$ See Dan L. Burk, Patenting Speech, 79 TEX. L. Rev. 99 (2000).

11 Id.

12 See Dan L. Burk, Reflections in a Darkling Glass: A Comparative Contemplation of the Harvard College Decision, 39 CAN. BUS. L.J. 219 (2003).

${ }_{13}$ See Pamela Samuelson et al., A Manifesto Concerning the Legal Protection of Computer Programs, 94 ColuM. L. Rev. 2308 (1994).

${ }^{14}$ See Burk \& McDonnell, supra note 7.

${ }^{15}$ Stanley M. Besen \& Leo J. Raskind, An Introduction to the Law and Economics of Intellectual Property, 5 J. ECON. PeRsPECTIVES 3 (1991). 
implementation is highly uncertain.

Given the uncertain ratio of cost to benefit for any patent, numerous commentators have challenged the expansion of patent law. Some have argued that on doctrinal grounds, the patent statute contemplates technological rather than business-oriented subject matter. $^{16}$ Other commentators have questioned the procedural feasibility of business method patents - the Patent Office has little expertise in evaluating business-related innovation. ${ }^{17}$ Yet other commentators have challenged the policy basis for such patents; there is little evidence that development of business methods requires the extra incentive provided by intellectual property or that the costs of bestowing exclusive rights on such innovations will be exceeded by the social gain in business innovation. ${ }^{18}$

For all of these reasons, foreign patent examination corps, especially the European Patent Office (EPO) have been fighting a losing rearguard action to resist such patents, demanding that patent applications have a "technical" aspect to them - a criterion intended to exclude business methods and related subject matter. ${ }^{19}$ But in the United States, given the structure of the patent system, patenting of tax planning methods was probably inevitable once software patents became the norm. ${ }^{20}$ If software is patentable, some number of software implementations will be business related, opening the door to patenting of business methods. If business methods are patentable, some number of those business methods will concern investment strategies. If investment strategies are patentable, some number of those strategies will concern tax planning. QED.

We return to this question in more detail in Part VII, where we examine the desirability of business method patents for tax planning strategies. Here our point is that the specific questions regarding tax planning patents do not exist in a vacuum; they are inextricably tied to the general questions regarding business method patenting. Consequently, any discussion of the effects of tax planning patents must begin by considering the effects of business method patents; having considered the characteristics of the business method genus, we can turn to the peculiarities of the tax planning species. We

${ }^{16}$ See Thomas, supra note 6.

17 See Robert P. Merges, As Many as Six Impossible Patents Before Breakfast: Property Rights for Business Concepts and Patent System Reform, 14 BERKELEY TECH. L.J. 577 (1999).

${ }^{18}$ See Dreyfuss, supra note 6; Raskind, supra note 6.

19 See Burk, supra note 12 , at 226.

${ }^{20}$ See id. at 225. 
approach both classes of patent from the standpoint of confidentiality and disclosure, since these are not only key considerations in implementing investment strategy, but are also key considerations in justifying the patent system generally. The issue common to all these contexts is the cost of controlling of valuable information, which frames the discussion of tax planning patents.

\section{BUSINESS PATENTS IN AN EFFICIENT MARKET}

While critics have questioned how well business method patents fit standard patent justifications, that is, regarding their ability to provide economic incentives for innovation, the special economic peculiarities of such patents have received less scrutiny. In particular, desirability of investment patents may deserve consideration in light of the efficient market hypothesis. In its strongest form, this economic theory holds that the prices in markets reflect all the available information concerning traded commodities, so that excess returns to investment are impossible. Weaker forms of this hypothesis hold that some temporary disparity between market price and actual value may be possible, allowing some excess returns to those who have access to better value information, but that the very activity of pursuing undervalued commodities will cause their prices to rise, rapidly dissipating any advantage gained from the privately-held information. In other words, the communicative nature of prices in markets rapidly, although perhaps not instantaneously, makes privately held investment information public. ${ }^{21}$

This hypothesis has important implications for investment strategies generally and for the policy of patenting such strategies. Investment strategies, whether patented or unpatented, are almost by definition intended to outperform the market - there is no other reason for the development of such strategies, since the recognized, understood, and simple approach of buying and holding a diverse portfolio of investment instruments would otherwise yield the optimal

${ }^{21}$ See Eugene Fama, Efficient Capital Markets: $A$ Review of Theory and Empirical Work, 25 J. FIN. 383 (1970) (providing the pivotal early statement of the efficient capital markets hypothesis). In recent years the hypothesis has undergone something of a battering among economists. See ANDREI SHLEIFER, INEFFICIENT MARKETS: AN INTRODUCTION TO BEHAVIORAL FINANCE (2000). The pivotal early treatment within legal scholarship is Ronald J. Gilson \& Reinier H. Kraakman, The Mechanisms of Market Efficiency, 70 VA. L. REV. 549 (1984). For a recent evaluation of market efficiency by a variety of leading corporate law scholars, see Symposium: Revisiting the Mechanisms of Market Efficiency, 28 J. CORP. L. 499 (2003). 
outcome. The efficient market hypothesis predicts that attempts to outperform an efficiently functioning market will fail. However, an investment strategy that may be exploiting some imperfection or inefficiency in the market may yield better returns than the market as a whole, at least until the information about the inefficiency leaks out, attracts other investment, and the profits from that investment anomaly are competed away. ${ }^{22}$

The question for investment strategies based upon anomalies, then, is how quickly they will be noticed and dissipated. If the market is sufficiently transparent, this may occur simply by observation of pricing in the marketplace. If for some reason market pricing does not reflect the desirability of the investment strategy, the information may reach the marketplace through other channels - such as gossip. Opportunism or entrepreneurship on the part of those conducting the investment transaction may also play an important role in disseminating information about the strategy. Employees familiar with the strategy may personally employ it for their own benefit or may use the information gained in the service of the firm to service their own clients, perhaps by leaving and founding their own brokerage. Indeed, competing investment firms may attempt to hire experienced personnel away from their competitors in order to get the benefit of that competitor's specialized knowledge for their own clients.

This of course presents a problem of confidentiality for those exploiting market anomalies. One strategy for containing such information leakage is to treat the investment strategy as a trade secret, prohibiting employees from discussing it with those outside the firm, from using the information for their own benefit, or from using the information in the service of a new employer. Obligations of trade secrecy arise from a number of legal sources, including a duty of loyalty to the employer in tort and prohibitions on unjust enrichment in the law of restitution. But a common source of trade secrecy obligation arises out of contract, through employment of confidentiality agreements and possibly non-competition agreements.

${ }^{22}$ Some investment strategies may not target temporary inefficiencies in generally efficient markets. They may instead be targeting markets that are very far from being efficient markets - for instance, venture capital targets the market for start-up companies, a market that is not close to being informationally efficient. Or, investment strategies may be targeting opportunities due to lasting inefficiencies that are created and maintained by governmental regulation which prevents market corrections from occurring. The latter may be of particular relevance in thinking about tax planning. 
These agreements may be used to obligate not only employees to secrecy, but also clients who will learn of the transaction, as well as business entities that may be involved in transactions under the investment system.

Such agreements are common in many industries, but may be central to preserving the profitability of investment strategies that are profitable only so long as the market does not learn of their existence. Yet confidentiality agreements are cumbersome to draft, to police, and to enforce. They are also subject to the famous "information disclosure paradox" formulated by Kenneth Arrow: the possessor of valuable information will be reluctant to disclose information unless a confidentiality agreement is in place, but the potential recipient of the information will simultaneously be reluctant to sign a disclosure agreement until he knows what information is to be disclosed. ${ }^{23}$ Consequently, Arrow predicts that disclosures under confidentiality agreement will be impeded and often will not occur at all.

Patents present one solution to the information disclosure paradox, by occasioning exclusive rights on the publication of an enabling disclosure of the claimed invention. ${ }^{24}$ An important factor in the calculus of patent benefits is the public benefit of disclosure. In order to obtain a patent, the applicant must disclose the claimed invention in sufficient detail that one of ordinary skill in the pertinent art could make and use the invention by following the disclosure. ${ }^{25}$ This disclosure is published as part of the patent document, providing the benefit of the information to the public at large and allowing anyone to practice the invention after the expiration of the exclusive rights in the patented invention. In the rationale of the patent system, disclosure of the invention is the public's quid pro quo for granting the inventor exclusive rights.

But quite apart from such public benefits to disclosure is a private benefit for negotiation and licensing transactions. The publication of the invention disclosure in a patent places potential licensees or purchasers on notice as to the nature of the invention, while the exclusive rights in the invention prevent misappropriation based on the disclosure. ${ }^{26}$ Thus, aside from any effect they may have as an

${ }^{23}$ Kenneth J. Arrow, Economic Welfare and the Allocation of Resources for Innovation, in THE RATE AND DIRECTION OF INCENTIVE ACTIVITY 609 (Richard R. Nelson ed., 1962).

${ }^{24}$ See Edmund W. Kitch, The Nature and Function of the Patent System, 20 J.L. \& ECON. 265, 277-78 (1977).

${ }^{25} 35$ U.S.C. $\$ 112$ II 1 (2006).

${ }^{26}$ See Kitch, supra note 24. 
incentive to investment or any benefit due to the increase in public knowledge, patents are expected to lower transaction costs between firms by avoiding the information disclosure stand-off that may occur under purely contractual disclosures.

However, the public information function of patents remains troublesome. The corpus of published patent disclosures unquestionably provides a valuable technical library to the public. But careful observers of the patent system have long been aware of a paradox in the patent disclosure rationale. ${ }^{27}$ The exclusive rights in a patent are only valuable in comparison to the patent holder's next best alternative, which is trade secrecy. Patent protection lasts for a little less than twenty years, but trade secrecy lasts so long as the invention remains generally unknown - essentially, so long as it is not independently recreated or reverse engineered by another. A rational innovator would prefer perpetual protection to twenty years of protection, and so would presumably opt for trade secrecy if the invention can be maintained as a secret. This in turn implies that the rational innovator will opt for a patent only when the invention cannot be maintained as a secret. Or, in other words, patents only disclose information which would have become public anyway.

Where investment methods are concerned, this problem is even more troubling. On a strong theory of the efficient market, information about investment strategies will by their very implementation be communicated via the market and their benefits dissipated away by the response of other market participants. Patenting the investment strategy, however, may legally exclude other market participants from responding to the price information signaled by the behavior of the patent holder - in other words, patents may lock in inefficiencies that the market would have corrected. On this view, the patent grant not only exchanges exclusive rights for information the public would have had anyway, it also locks in a market distortion for a period of nearly two decades. And since, on a strong theory of the efficient market, investment strategies would be impossible to maintain in secrecy, the incentive of a patent never prompts disclosure of otherwise inaccessible information.

On a weaker view of the efficient market, the prospects for patent disclosure may be somewhat less bleak. Patenting will presumably still not be an attractive option for investment strategies that might remain viable and confidential indefinitely. However, it may be that

${ }^{27}$ See Richard H. Stern, A Reexamination of Preemption of State Trade Secret Law After Kewanee, 42 Geo. WASH L. REV. 927, 958 (1974). 
the patent will prompt disclosure sooner in those cases where the investment strategy could not be maintained in secret for seventeen or eighteen years, but might have been maintained for a significant period of time less than that. Risk averse business innovators may opt for a certain seventeen or eighteen years of exclusivity over a lesser period of uncertain use, during which the strategy might be inadvertently disclosed or independently discovered by another (and, indeed, patented after independent discovery by another business innovator, in which case the earlier innovator will be excluded or end up paying patent royalties to the later discoverer). We suspect that it is in this class of investment strategies where patenting will have the greatest effect, particularly for tax investment strategies. And so it is in this class of investment strategies that we consider the effects of the shift from trade secrecy to patenting, in light of the theory of the firm.

\section{PATENTS AND THE THEORY OF THE FIRM}

Notwithstanding the indeterminacy of intellectual property's incentive costs to benefit ratio and the dubious rationale for patents on a theory of disclosure, patenting may have other welfare enhancing benefits. Some commentators recently have begun looking at the potential benefits of intellectual property grounded in the theory of the firm, as articulated by Ronald Coase and subsequent contributors. $^{28}$ The theory of the firm argues that the size and structure of firms will be determined by the relative cost of transactions in a structured hierarchy versus in the open marketplace. $^{29}$ At some organizational size, for some purposes, a command and control type of hierarchy will be more efficient than market negotiations. Firms will form and grow to the point where the efficiencies of hierarchy are supplanted by the efficiencies of market competition.

Modern theories of the firm have identified property rights, including intellectual property rights, as important instruments in

${ }^{28}$ See, e.g., Ashish Arora \& Robert P. Merges, Specialized Supply Firms, Property Rights and Firm Boundaries, 13 Indus. \& CORP. CHANGE 451 (2004); Robert P. Merges, A Transactional View of Property Rights, 20 BERKELEy TECH. L.J. 1477 (2005); Oren Bar-Gill \& Gideon Parchomovsky, Intellectual Property Law and the Boundaries of the Firm (Univ. of Penn Inst. for Law \& Econ. Research Paper No. 0419, 2004), available at $\mathrm{http}: / / \mathrm{ssrn} . \mathrm{com} / \mathrm{abstract}=559195$.

29 Ronald H. Coase, The Nature of the Firm, 4 ECONOMICA 386 (1937). Early work by Professor Frank Knight addresses similar questions. See F. H. KNIGHT, RISK, UNCERTAINTY AND PROFIT (1921). 
lowering transaction costs in the market. ${ }^{30}$ Firms may negotiate with one another for production inputs and outputs, but the contracts covering such bargains will not foresee every contingency, and business partners may take such ambiguities as occasions to act opportunistically. Property rights serve as default rules to allocate resources when contracts are incomplete and parties behave opportunistically. Intellectual property may be especially important to such transactions, because unlike physical property, over which control can be maintained by actual possession, control over valuable information is surrendered as soon as it is revealed to a business partner. The availability of such residual rights in a firm's assets lowers transaction costs between firms, by providing some degree of security when bargained-for deals go sour.

At the same time, property rights, including intellectual property, may lower transaction costs within the firm as well. ${ }^{31}$ The interactions of organizational divisions and personnel within the boundary of the firm may also be costly and uncertain, leaving room for shirking, selfdealing, and other opportunistic behaviors. Property rights help to ameliorate such behaviors, by securing legal ownership of the firm's assets to the firm and allocating the fruits of production between employee and employer. Intellectual property may be particularly important to employee mobility, by defining what types of intellectual assets may be taken by employees leaving the firm for new opportunities and what assets remain the assets of the firm they leave behind.

In previous work we have explored in detail the role of intellectual property rights in lowering transaction costs both within firms and between firms. ${ }^{32}$ Since Coase and his successors predict that the boundary of the firm will be determined based upon the relative cost of transactions within the firm and between firms, we have argued that the optimal intellectual property regime must consider the interplay between both sets of costs. In some instances, a weak property regime such as trade secrecy will do too little to prevent employees or business partners from misappropriating the firm's knowledge assets. In other instances, a strong property regime such as patents will overly hamper employee entrepreneurship within the firm

30 Oliver D. Hart, Firms, Contracts, and Financial Structure (1995); David J. Teece, Profiting from Technological Innovation: Implications for Integration, Collaboration, Licensing and Public Policy, 15 RES. POL'Y 285 (1986).

${ }^{31}$ Dan L. Burk, Intellectual Property and the Firm, 71 U. CHI. L. REv. 3 (2004); Paul Heald, A Transaction Costs Theory of Patent Law, 66 OHIO ST. L.J. 473 (2005).

${ }^{32}$ See Burk \& McDonnell, supra note 7, at 576-77, 587-90. 
and negotiations between firms. Thus, we have argued that to strike the proper balance of transaction costs between firms and within firms, intellectual property regimes must be calibrated "just right." For some industries and their constituent firms, the optimal regime might be a weak misappropriation right such as trade secrecy, but for others the optimal regime might be a strong property system such as patenting.

We have also suggested that a focus of particular scholarly interest should be industries that are transitioning between intellectual property regimes, for it is there that the effects of different forms of intellectual property on transaction costs should be most apparent. ${ }^{34}$ The adoption of patent protection for tax planning strategies represents just such a transition, from a regime of confidentiality to a regime of strong exclusive rights - effectively from trade secrecy to patent. Even more than other investment strategies, tax shelters are likely to rely on confidentiality to remain viable. First, a stampede of investors toward a particular method of investment that exploits an unanticipated outcome of the tax system is likely to attract unfavorable attention from the Internal Revenue Service (Service) and Congress due to lost revenue; either legislative or administrative action may result to close the loophole. Additionally, to the extent that the shelter is dubious or possibly illegal, open disclosure may prompt administrative action including prosecution, fines, or penalties. Because of these additional concerns, the Service has issued rules requiring disclosure of potentially problematic investments, not to the public, but to the Service itself. The availability of patents as an alternative to confidentiality changes the transaction cost picture in each of these considerations.

\section{TAX Planning Without Business Method Patents}

The theory of the firm may therefore have a good deal to tell us about the consequences of tax shelter patenting, particularly about the effects of such patents on firms that offer tax advice and on the employees of such firms. Consider first the structure of the tax planning industry and firms that engage in tax planning before the introduction of business method patents. This was a regime of weak property rights - innovators in tax planning had to either rely on trade secrecy or else let others use their innovations without

\footnotetext{
${ }^{33}$ Id. at 577.

${ }^{34}$ Id. at 636.
} 
compensation. What were the effects of that regime on the incentives to innovate and to spread the use of new strategies? How did the weak property right regime affect the relative attractiveness of innovating and developing new strategies within firms versus between firms, and hence how did it affect the boundaries of firms within the industry?

As just mentioned, firms may respond to the absence of strong property rights (i.e. patents) by pursuing one of two strategies: protecting innovations via trade secrecy or just letting others take their ideas. Consider the trade secrecy strategy first. A firm with an idea for a new tax planning strategy may want to partner up with another firm or firms, either in developing the basic idea or else in letting the other firm develop modified versions of the basic strategy. However, here Arrow's Information Disclosure Paradox ${ }^{35}$ arises: in negotiating with such potential partners the innovator will be afraid that if the partner learns about its idea, the partner will be able to use the idea for its own without compensation. Innovators can respond in two basic ways. They might refuse to share their ideas with any partners and keep them hidden from potential competitors or else they might negotiate confidentiality agreements with potential partners before sharing ideas. Both approaches tend to slow down the rate at which new planning strategies will diffuse among firms within the industry.

Similarly, the lack of the patent option also affects the relationship of firms with their employees. Its employees generate a firm's new planning strategies, and the set of its existing strategies exist within the minds of its employees. A firm trying to keep its competitors from copying its innovations must worry about its employees leaving to go work for those competitors, taking the ideas behind the innovations with them. A firm following a trade secrecy strategy will try to stop its employees from doing this. One way to do so is to have its employees sign non-competition agreements, at least where and to the extent that such agreements are legally valid. Another way to do so is to have their employees sign confidentiality agreements or in other ways agree not to use the firm's trade secrets if they go to work for others. This in turn will make the employees less attractive in the job market, as competitors are worried about what the employees will and will not be able to use if they come and work for them. Thus, in several ways a trade secrecy strategy will limit inter-firm mobility of employees, in turn reducing the spread of new

35. See supra note 23 and accompanying text. 
planning strategies across firms.

The other strategy that firms might follow, in the absence of patents, is to simply not take any special precautions against competitors stealing their innovations in planning strategies. Even without such precautions it will naturally take some time for new ideas to spread through the industry, and a firm may profit from its innovation during the interval before competitors have adopted the innovation as well. ${ }^{36}$ Such reliance on "first mover advantage" may be more attractive in the tax planning industry that in many others in that the useful life of many tax planning strategies, particularly abusive ones, is quite short. A firm and its clients can benefit from an abusive strategy only until the Service catches on and shuts down use of the strategy. It may be that this time period is short enough that few competitors will catch on in that time, and hence taking expensive precautions against being copied does not make sense. On the other hand, non-abusive strategies may continue to be used for a very long time, and so for such strategies, allowing one's competitors to copy will be more costly.

The results for industry structure and innovation depend on whether most firms usually follow a policy of secrecy or openness. The secrecy strategy slows the diffusion of new planning strategies across the industry. It also reduces employee mobility. On the other hand, it probably creates a stronger incentive to innovate in the first place, as innovators profit from their ideas for a longer time. This effect is complicated, though, by the fact that would-be innovators will be less aware of what their competitors are doing, and hence less able to borrow ideas from them. Particularly with the trade secrecy strategy there will be a tendency to relatively large firm size, as employees tend not to move and start up new firms and as older firms tend not to take on new ideas from innovative start-ups. For both reasons, there is less incentive for persons with interesting new tax planning strategies to go out and start up a new firm to develop, promote, and use that strategy.

\section{Tax Planning with Business Method Patents}

What happens to the scenario we have described when one introduces a possible new strategy for tax planners, namely the option of patenting new planning strategies? The comparison to a regime

${ }^{36}$ This is how markets work, and informational inefficiencies are corrected. See Sanford J. Grossman \& Joseph E. Stiglitz, On the Impossibility of Informationally Efficient Markets, 70 AMER. ECON. REV. 393 (1980). 
without patents depends in part upon whether a firm that now decides to patent would otherwise have followed an approach of trade secrecy or of no protection. We assume that most firms that decide to patent a new strategy would have otherwise followed a trade secrecy approach. The expense of patenting will be worth incurring only if one expects a new strategy to be profitable for a long period of time. As we saw before, where that is true the trade secrecy strategy is more likely to be the more profitable approach as compared with no protection.

With a patent, a firm will have less fear of competitors copying its strategy, because if competitors do so, the firm will be able to take legal action to stop the infringement. Thus, the firm does not need to protect the idea via confidentiality agreements with its partners and its employees or via non-competition agreements with the latter. ${ }^{37}$ The firm will be more willing to enter into arrangements with other firms to create, develop, and modify new planning strategies. Employees will be able to move between firms more easily, both because they are not subject to non-competes and also because they and their new employers will have a clearer sense regarding which ideas can and cannot be transferred with the employees from their old jobs. ${ }^{38}$

These changes are likely to have a decided effect on the creation, development, and diffusion of new tax planning strategies. New strategies will diffuse across firms more rapidly, as firms are more willing to share new strategies with business partners and as employees circulate more rapidly among different firms, taking their knowledge with them. ${ }^{39}$ As these new strategies spread across firms, they will be modified and adapted into yet more new strategies. The creation of tax planning strategies is modular and cumulative - more complicated new ideas draw upon the elements of earlier, simpler strategies. $^{40}$ There will also be a somewhat increased incentive to develop new strategies as their creators are able to profit from the use of their strategies by others.

As our discussion of intellectual property and the theory of the firm suggests, this kind of change in the availability of proprietary rights is also likely to have effects on firm size and industrial structure. On balance, we would expect to see a move to something closer to the

${ }^{37}$ See Burk \& McDonnell, supra note 7, at 629-32.

${ }^{38}$ See id. at 632.

${ }^{39}$ See Arora \& Merges, supra note 28, at 629.

${ }^{40}$ On the general production process for complex transactional documents, see Claire A. Hill, A Comment on Language and Names in Complex Business Contracting, 77 CHI.-KENT L. REv. 29 (2001). 
so-called "Silicon Valley model." Scholars who have studied the development and success of Silicon Valley have argued that innovation occurs because of employee mobility among firms, which seems in turn to be due to the relative lack of non-competition agreements and trade secrecy enforcement. ${ }^{41}$ Similarly, in the tax planning industry, the introduction of patents may better allow entrepreneurial employees to launch innovative start-ups that have developed new planning strategies. If successful, these start-ups or spin-out firms will be able to license these strategies to others. Both increased employee mobility and greater ease of contracting with other firms tend to push in that direction.

There are a few counter-effects that could push the tax planning industry in a different direction. For one, the standard short-term effect of granting a degree of monopolistic power ${ }^{42}$ to innovators may discourage diffusion to some competitors. Competitors will have to pay a licensing fee to use a patented strategy, and some may be unwilling to do so. If the patent holders could perfectly price discriminate, this would not be a problem, but perfect price discrimination is typically not possible. ${ }^{43}$

More interesting and serious is the possibility that patents could create an anticommons in tax planning. Scholars studying the proliferation of real property rights have held that granting rights to too many small parcels of land can create a "tragedy of the anticommons" - the inverse of the classic tragedy of the commons. ${ }^{44}$ Property rights are typically granted as the private ordering solution

41 Alan Hyde, Working in Silicon Valley: ECONOMIC AND Legal ANalysis of a High-Velocity Labor Market (2003); AnNaleE SaXenian, Regional Advantage: Culture and Competition in Silicon Valley and ROUTE 128 (1994); Ronald J. Gilson, The Legal Infrastructure of High Technology Industrial Districts: Silicon Valley, Route 128, and Covenants Not to Compete, 74 N.Y.U. L. REV. 575 (1999).

${ }^{42}$ Note that patents do not necessarily confer monopoly power. They do so only to the extent that there are no close substitutes for a particular patented good or service. See Edmund W. Kitch, Patents: Monopolies or Property Rights?, 8 REs. L. \& ECON. 31 (1986). Thus, the argument in the text applies only to patented tax planning strategies which are unique and valuable enough that users are willing to pay a premium for that strategy over competing possibilities.

${ }^{43}$ Daniel A. Farber \& Brett H. McDonnell, Why (and How) Fairness Matters at the IP/Antitrust Interface, 87 MINN. L. REv. 1817, 1867 (2003).

${ }^{44}$ See Michael A. Heller, The Tragedy of the Anticommons: Property in the Transition from Marx to Markets, 111 HARV. L. REV. 621 (1998). The original "tragedy of the commons" referred to the over-exploitation of a common resource. See Garrett Hardin, The Tragedy of the Commons, 162 SCI. 1243 (1968). 
to the tragedy of the commons; the inefficient over-use of resources. But too many property rights may lead to the inefficient under-use of resources. In this situation, property rights are too fragmented, and the transactions costs of negotiating with diverse property owners is too high, to accomplish comprehensive development projects. Some property owners may "hold-out" for excessive rents, inefficiently frustrating beneficial development that includes their parcel. Some follow-on scholarship has suggested that this same effect can occur with intellectual property, particularly with fragmented patent rights. ${ }^{45}$

In the case of tax planning, recall that creating new tax planning strategies is a cumulative and modular process that builds upon earlier strategies. If patents have a broad and vague scope, they may actually inhibit innovation. A would-be innovator might find that many firms hold patents on strategies that she could potentially use, and hence infringe upon, in her new strategy. The innovator would then need to negotiate licenses with the holders of the various patents. However, if there are many such holders and if the scope of their rights is unclear, negotiation may be costly and subject to breaking down. If these costs are high enough, they may stop some innovations from happening at all. The result may be less creation of new planning strategies and more limited diffusion than in the absence of patents. ${ }^{46}$

An extensive anticommons problem could also reverse the predicted effect on firm size. One way that firms may react to an anticommons problem is to integrate the holders of various complementary patents into one firm, thereby reducing or eliminating the anticommons problem. ${ }^{47}$ Thus, the effect of introducing business method patents for tax planning strategies could conceivably be to increase the size of firms within the tax planning industry, rather than decreasing firm size as predicted above.

This sort of ambiguity in predicted effects is unfortunately endemic when considering the effect of intellectual property law on firm size and structure. ${ }^{48}$ The effect of weak versus strong property

${ }^{45}$ Michael A. Heller \& Rebecca S. Eisenberg, Can Patents Deter Innovation? The Anticommons in Biomedical Research, 280 ScI. 698 (1998).

${ }^{46}$ The effect of patents on market informational efficiency that we discussed above may also complicate the analysis of innovation diffusion. Insofar as the basis for a strategy's profitability is identifying anomalies and exploiting them before the market corrects, then the inventors of such strategies are unlikely to license or allow their use by others, because use by others will inherently destroy the profitability of such a strategy.

${ }^{47}$ See Burk \& McDonnell, supra note 7, at 617.

${ }^{48}$ Id. at $617-25$. 
right protection on inter-firm and intra-firm transactions is typically non-monotonic. For instance, increasing the strength of inter-firm property protection from a weak level initially leads to smaller firm size, as more firms choose to do transactions between firms rather than within. However, if property protection continues to increase beyond an optimal level, the anticommons problem kicks in, and further increases in the strength of property rights above that level will lead to larger firm size. A similar effect, with the directions reversed, occurs for changes in property rights that affect intra-firm transaction costs.

What then are the likely net effects of introducing business method patents into the tax planning industry? We suspect that the anticommons problem is not likely to dominate, although this is just an educated guess - we have no systematic empirical support for it. Indeed, it is probably too soon in the evolution of the industry to be able to tell, since the proliferation of business method patents is relatively recent. That makes this an interesting industry to watch in the coming years, to see how the changes in patent law affects the industry.

If we are right about the relative unimportance of the anticommons problem here, then the overall effects will be as suggested above. Average firm size will decrease, and there will be more innovative start-ups peddling new tax planning strategies. Firms are also likely to become more specialized. The creation of new tax planning strategies will increase, and the new strategies will diffuse more rapidly across the industry.

\section{EVAluAting THE CONSEQUENCES OF BUSINESS METHOD PATENTS}

In the preceding parts we have considered the likely effects of business method patents for tax investment strategies on firm organization in the tax planning industry and on incentives to create and market new tax planning strategies. We found that the possible effects are complex and ambiguous. However, it seems to us most likely that the availability of business method patents will lead to smaller, more specialized, and more entrepreneurial firms providing a wider range of planning strategies, and also to faster diffusion of the new strategies.

For most goods and services, the normative evaluation of these effects would be relatively simple. Insofar as most goods and services that meet a market demand increase net social welfare, then a policy 
that leads to more creation and faster diffusion of those goods and services is generally a good thing. However, tax investment strategies may not be an ordinary service. There exists a fairly strong argument that such strategies create a net social harm - they induce citizens to waste resources on planning that lowers income to the government. ${ }^{49}$

Of course, this is to some extent a cost of adopting a tax system in the first place. Taxation itself introduces distortions into the market, changing the effective prices of goods and services, altering price signals, and so changing the output of goods and services in response to such signals. ${ }^{50}$ At its best, taxation aims to solve the problem of underproduction of public goods - the same problem addressed in part by the patent system. However, depending upon the placement of tax surcharges, the distortions created by taxation may run the gamut from intentional corrections for market failures, to intentional subsidies for politically favored outcomes, to unintentional penalties for otherwise productive activity.

If a tax investment strategy constitutes a deliberate governmental correction of a market failure, or subsidy or incentive toward a preferred type of economic activity, then patenting that strategy might frustrate Congressional purposes by excluding investors from the desired activity. This scenario seems unlikely to us, however, as patents must meet statutory criteria of novelty and non-obviousness. ${ }^{51}$ If a particular investment strategy has been openly contemplated and debated by Congress, that public discussion likely renders it obvious and publicly known, and so by definition unpatentable. In order to be "innovative," patentable tax shelters are likely to be previously unnoticed and probably unintended "loopholes" in the tax system.

We leave it to others in this symposium to argue whether nonabusive tax planning is a social bad. For this portion of our article, we assume that it is a bad, because that complicates our normative analysis. If you reject this assumption, you can ignore the remainder of this part, and simply conclude that business method patents are likely to have a net positive effect if our analysis in the preceding parts is correct.

Given our assumption regarding the downside of tax planning, does it make sense to use patent law as the preferred tool to

${ }^{49}$ For further discussion of this and of the subtle implications it may have for tax policy, see Philip A. Curry, Claire A. Hill \& Francesco Parisi, Creating Failures in the Market for Tax Planning, 26 VA. TAX REV. 943 (2007).

50 See HandBooK of Public FinanCE (J. Backhaus \& Richard E. Wagner, eds., 2004).

${ }^{51}$ See 35 U.S.C. $\$ \S 102(a), 103(a)(2006)$. 
intervene, in order to dampen the effect of business method patents toward increased use of new tax planning strategies? A simplistic initial answer might be to concentrate instead on Service enforcement as the best way to discourage tax planning strategies rather than tweaking patent law to achieve this goal. However, a relatively simple theory of the second-best approach ${ }^{\text {52 }}$ calls that answer into question. Service enforcement and rulemaking are highly imperfect in their ability to discourage inefficient planning strategies. Given such limitations, perhaps it makes sense to use another policy tool, patent law, to supplement the imperfect tool of tax law.

While this argument seems attractive, we believe that the initial simplistic answer is the right one: the better approach is to concentrate on tax law and on Service enforcement as the primary tools to combat unwanted tax planning and leave patent law out of tax policy. For one thing, business method patents will have some positive effects. More importantly, even if the negative effects outweigh the positive effects, as seems likely, there is just no way to fiddle with patent law as applied to tax planning without bad results in much bigger areas of patent law.

Consider both the static and dynamic effects of making business method patents available for tax planning. Start with the static effects. Insofar as a patent gives the patent holder some ability to raise its price above the competitive level, it will thereby reduce the amount provided given the existence of the service. Normally that's seen as a bad but necessary consequence of patenting. ${ }^{54}$ Here, it is a positive effect - it means that some people will not use a patented strategy who otherwise would because of what they will need to pay for the license to use the strategy. If we want to discourage the use of tax planning, that is a good thing.

Another possible positive effect is on public disclosure of tax planning strategies, which may affect the ease of Service enforcement. As in the case of other trade secrets, the availability of patents seems unlikely to prompt disclosure of tax investment strategies that would otherwise remain confidential indefinitely. However, patents might possibly assist in prompting the disclosure of tax shelters on the margin of confidentiality, that is, investment strategies unlikely to

${ }^{52}$ For an overview of the theory of the second best, see Richard S. Markovits, Second-Best Theory and Law \& Economics: An Introduction, 73 CHI.-KENT L. REv. 3, 3-10 (1998).

${ }^{53}$ See supra notes $12-20$ and accompanying text.

$\$ 4$ See Roger D. Blair \& Thomas F. Cotter, InTEllectual Property: ECONOMIC AND LEGAL DIMENSIONS OF RIGHTS AND REMEDIES 17 (2005). 
remain secret for longer than the term of the patent. To the extent that this occurs, patenting may actually be beneficial in allowing the Service to identify dubious investment schemes; the published patent applications may be one place where tax investment schemes can be monitored.

Of more consequence, though, is the long-run effect on innovation and diffusion of innovation. We focused mainly on this effect in the previous parts. Even there, we see some ambiguity. The anticommons effect could reduce the amount of innovation that occurs $^{55}$ - which again would be a good thing, in the topsy-turvy world where we do not want innovation in this particular service. Thus, trying to limit the patenting of tax strategies may be counterproductive if indeed the anticommons effect dominates.

Of course, we do not believe that it is likely to do so. Hence, we do need to face up to the likelihood that business method patents will encourage more innovation and diffusion of tax planning strategies in the long run, and that may indeed be disturbing. Under this scenario, we must consider whether such a proliferation of tax planning strategies can be curtailed through patent law. Recall our earlier discussion of the slippery slope that led to business method patents for tax planning strategies in the first place. ${ }^{56}$ Given the inexorable transition from software patents to business method patents to tax shelter patents, is there anyplace on this slope where patent policy can call a halt to the slide? One could of course imagine attempting at several junctures to hold the line. Moving from the specific to the more general, one might try to hold the line against acceptance of abusive tax planning patents, or against acceptance of all tax planning patents, or of investment strategy patents, or of business method patents, or for that matter of software patents.

But this strategy is doomed by what Mark Lemley and Julie Cohen have in the software context called "the doctrine of the magic words" - past prohibitions against software patents were easily elided by drafting patent claims so as to avoid the term "software" and instead drafting in terms of some other subject matter - the state of a wrist watch or the function of a pizza oven, perhaps. ${ }^{57}$ The patent issues just the same, and covers the software, but in terms that thinly disguise the subject matter. This was the situation in the United

55 See supra notes $44-47$ and accompanying text.

56 See supra notes 12-20 and accompanying text.

57 Julie E. Cohen \& Mark A. Lemley, Patent Scope and Innovation in the Software Industry, 89 CAL. L. REV. 1 (2001). 
States until the United States Court of Appeals for the Federal Circuit declared an end to the façade in its State Street decision; it remains the case today in foreign patent offices such as the EPO. ${ }^{58}$ Even under a subject matter prohibition, one can always get a software patent, so long as it is denominated properly in the claims.

Much the same result could be expected of attempts to block investment or tax planning patents - avoiding such prohibitions simply becomes a claims drafting exercise in avoiding certain terminology. There is no particular reason that the claims of a tax planning method patent need mention "tax shelter" or even the word "tax." To be sure, the patent must disclose some utility for the investment system, but so long as that disclosure is couched in the terminology of investment rather than the terminology of taxation, there may be little or nothing to distinguish the application from other applications drawn to business methods. Detailed scrutiny of the patent disclosure by someone having the relevant tax or accounting experience might winnow out investment method patents that would confer, but do not explicitly state, a tax advantage. But the Patent Office examination corps has little experience in such matters, and a given patent application typically does not undergo such detailed examination.

Alternatively, since the interpretation of the patent statute by courts and by the Patent Office has led to the "let it all in" approach to subject matter, there have been calls for Congress to intervene, at least with regard to tax shelter patents. ${ }^{59}$ But legislation on the matter is probably neither feasible nor desirable. First, Congressional attention to intellectual property reform is at best sporadic and tenuous, as there is typically little collective incentive to address such matters - patent law seldom commands the attention of the electorate or the press such that an enormous amount of political capital is needed to muster the necessary votes. ${ }^{60}$ At various times various constituencies have raised a hue and cry over a range of subject matters that they felt should be barred from patentability: gene patents, animal patents, software patents, and many others. ${ }^{61}$

58 See Burk, supra note 12 , at 226.

59 See e.g., Editorial, Pay to Obey, N.Y. TIMES, Oct. 31, 2006, at 24.

${ }^{60}$ See Burk, supra note 12, at 232.

${ }^{61}$ See, e.g., Rebecca Dresser, Ethical and Legal Issues in Patenting New Animal Life, 28 JURIMETRICS J. 399 (1988) (discussing opposition to animal patents); Rebecca S. Eisenberg, How Can You Patent Genes?, in Who Owns LifE? 117 (David Magnus et al. eds., 2002) (discussing opposition to gene patents); Cynthia M. Ho, Patents, Patients, and Public Policy: An Incomplete Intersection at 35 U.S.C. $\$ 287($ c), 33 U.C. 
Despite what are often poignant and frequently compelling reasons to bar such patents, these efforts have seldom resulted in any concrete legislative action.

Moreover, on the rare occasion when legislative response has occurred, there is usually reason to wish that it hadn't. The previous history of remedial legislation regarding patentable subject matter is not encouraging. ${ }^{62}$ Congress has in the past enacted specialized statutes to ameliorate the perceived shortcomings of surgical and medical process patents, precluding enforcement of such patents in some cases. $^{63}$ Congress also enacted legislation to address the unfairness of business method patents, carving out a prior user exception to enforcement of such patents in some cases. ${ }^{64}$ Neither provision was well-drafted or considered, each is opaque and nearly incomprehensible, and both provisions remain obscure and largely unnoticed. Legislative attention to tax shelter patents, should there be any, could well produce equally undesirable outcomes.

One thing that the Patent Office might conceivably be able to do is to police the creation of overly broad or vague patents better than it currently does. Even this, though, is not necessarily a good use of Patent Office resources - most patents are never enforced anyway and there is a fairly strong argument to be made for waiting to police patents at the point of enforcement, rather than trying to guess early on which might prove to be mischievous. ${ }^{65}$ More fundamentally, for our story here, overly broad or vague patents would be a good thing in the tax strategy area, given our assumption that tax strategy is a social bad. After all, overly broad and vague patents are the source of the anticommons problem, and in this area we would like to encourage the creation of an anticommons.

\section{CONCLUSION}

We suspect the discussion in Part VII may be of most interest to tax scholars and attorneys who read this paper. Given the general

DAVIS L. REV. 601 (2000) (discussing opposition to medical process patents); Allen Newell, The Models are Broken, The Models are Broken!, 47 U. PITT. L. REV. 1023 (1986) (discussing opposition to software patents).

${ }^{62}$ See Dan L. Burk \& Mark A. Lemley, Policy Levers in Patent Law, 89 VA. L. REV. 1575, 1630-38 (2003).

${ }^{63} 35$ U.S.C. $\$ 287(c)(2006)$.

${ }^{64} 35$ U.S.C. $\$ 273$ (2006).

${ }^{65}$ See Mark A. Lemley, Rational Ignorance at the Patent Office, 95 Nw. U. L. REV. 1495, 1501 (2001). 
focus of most tax scholars on trying to discourage too much use of tax investment strategies, encouraging such strategies through patent policy does seem rather odd. However, for the reasons we have catalogued, it is probably not feasible to do much about this from the standpoint of patent law. So long as the courts remain committed to recognizing business method patents, then patents for tax investment strategies are here to stay. Both tax and investment professionals and the Service are simply going to have to deal with the consequences.

Of most interest to us is how tax and investment professionals are likely to respond and in particular how those responses will affect business and industrial organization in their industry. We have shown that business method patents may set in motion a variety of effects that point in differing directions. However, the most likely net effects are that the availability of business method patents for tax investment strategies will lead to smaller, more specialized, and entrepreneurial firms in the business of tax planning and will result in more new planning strategies which will diffuse more quickly.

Business method patents obviously raise issues well outside the field of tax planning. All areas of the legal, accounting, and investing professions are potentially affected by this development. The theoretical apparatus we have applied in this article to the field of tax planning can be used and tested more broadly to help consider the broader effects of business method patents. While exploration of those effects is an important and interesting undertaking, we leave that for another day. 